\title{
A $\beta$-Glucosidase Activity Potentially Involved in Cell Division and Wall Development of Phyllostachys Bamboo Suspension Cells
}

\author{
Shinjiro Ogita*, Shinya Ohki, Taiji Nomura, Yasuo Kato \\ Laboratory of Plant and Cell Engineering, Department of Biotechnology, Toyama Prefectural University, Toyama, Japan. \\ Email: ${ }^{*}$ ogita@pu-toyama.ac.jp
}

Received May $29^{\text {th }}, 2012$; revised June $27^{\text {th }}, 2012$; accepted July $10^{\text {th }}, 2012$

\begin{abstract}
We propose a novel Madake (Phyllostachys bambusoides) bamboo suspension culture model for investigation of key enzyme(s) activity involved in growth/differentiation. Sedimented Cell Volume (SCV) and fresh weight (FW) of the suspension cultured cells reached $34 \%(\mathrm{v} / \mathrm{v})$ and $8.7 \mathrm{~g}$ in $10 \mu \mathrm{M}$ 2,4-dichlorophenoxyacetic acid (2,4-D)-containing medium while only $7 \%(\mathrm{v} / \mathrm{v}) \mathrm{SCV}$ and $1.9 \mathrm{~g} \mathrm{FW}$ of the cells in $10 \mu \mathrm{M}$ gibberellic acid $\left(\mathrm{GA}_{3}\right)$-containing medium in 14 days. Proportion of mitotically active cells ( $\mathrm{S}$ to $\mathrm{G}_{2} / \mathrm{M}$ phases) at a $\log$ phase was identified as $29.5 \%$ in the former cells with tiny cytoplasmic features while $5.4 \%$ in the latter cells with elongation, wall thickening, and lignification by using flow cytometry and laser scanning microscopic analysis. The total $\beta$-glucosidase (BGL) activity under the 2,4-D condition increased from $4.8 \mathrm{U}$ in day 2 to $26.2 \mathrm{U}$ in day 14 (ca. 5.5-fold) while a slight reduction, from $4.4 \mathrm{U}$ in day 2 to $2.1 \mathrm{U}$ in day 14 (ca. 0.5 -fold), occurred when cell division was suppressed under the $\mathrm{GA}_{3}$ condition. Ratio of the BGL activity of the soluble fractions to the membrane-associated fractions varied depending of the culture condition. The ratio was stable ( 2 to 8 ) during the culture period under the 2,4-D condition. Interestingly, the activity of the soluble enzyme fractions increased up to ca. $65 \%$ under the $\mathrm{GA}_{3}$ condition in inverse proportion to the membrane-associated enzymes. All together, it was strongly suggested that the detected specificity/variability of BGL activity is potentially involved in cell division and lignification in Madake bamboo cells.
\end{abstract}

Keywords: Bamboo; $\beta$-Glucosidase; Cell Wall Development; Phyllostachys bambusoides; Suspension Culture

\section{Introduction}

The genus Phyllostachys is one of the largest genera of bamboo distributed mainly in the East Asia. As bamboos are fast-growing plants and have high carbon fixation ability, they are expected as renewable resources for biomass production and a potential modulator of global environment [1]. With the aim of elucidating growth features such as cell division and wall development, we previously developed callus and suspension cell culture of Phyllostachys bamboo. The bamboo suspension cells had a high proliferation potential with abundant deposition of $\beta$-glucan compounds [2]. We also reported the growth and carbohydrates $(\mathrm{CH})$ metabolic features of suspension cells of Hachiku (P. nigra) bamboo in comparison with rice Oc cells [3], and tobacco BY-2 cells [4]. The profiles of sucrose degradation and uptake of the resulted monosaccharides, fructose and glucose, in the media indicated one of the evidences that bamboo cells have a unique

\footnotetext{
"Corresponding author.
}

feature of $\mathrm{CH}$ metabolisms [5].

We firstly examined three $\mathrm{CH}$ (sucrose, maltose, and cellobiose)-degrading activity of a novel Madake ( $P$. bambusoides) bamboo cultured cells in comparison with that of bamboo intact tissues, such as shoots, axillary shoots, leaves, nodes, and culms. As the bamboo cells showed a unique feature of cellobiose degradation (Table 1), we then focused on an activity of the enzyme, $\beta$ glucosidase (BGL), potentially responsible for its degradation. As reviewed by Cairns and Esen [6], BGLs play important roles in cell wall development, lignification, $\beta$-glucan turnover, phytohormone activation, defense, and release of aromatic compounds in plants. We established a contrastive medium condition, i.e. proliferation (modified half strength Murashige and Skoog [7] medium (m1/2MS) in the presence of 2,4-D) and lignification ( $\mathrm{m} 1 / 2 \mathrm{MS}$ in the presence of $\mathrm{GA}_{3}$ ), and identified proportion of BGL activity of the soluble and the membrane-associated enzyme fractions in our bamboo suspension cell culture model with monitoring the fre- 
Table 1. CH-degrading activity in cells/tissues of $P$. bambusoides.

\begin{tabular}{lcccc}
\hline \multirow{2}{*}{ Cells/tissues } & DW/FD & \multicolumn{3}{c}{ CH-degrading activity $(\mu \mathrm{mol} / \mathrm{h} / \mathrm{mg} \mathrm{DW})$} \\
\cline { 3 - 5 } & & Sucrose & Maltose & Cellobiose \\
\hline Suspension cells & 0.070 & 3.4 & 2.5 & 4.1 \\
Shoots (top) & 0.10 & 9.7 & 0.53 & 1.3 \\
Shoots (base) & 0.090 & 11 & 0.71 & 2.0 \\
Axillary shoots & 0.45 & 0.81 & 0.26 & 0.86 \\
Leaves (immature) & 0.47 & 1.1 & 0.32 & 0.76 \\
Leaves (mature) & 0.53 & 0.99 & 0.29 & 0.21 \\
Nodes & 0.72 & 0.11 & 0.12 & 0.26 \\
Culms & 0.61 & 0.36 & 0.070 & 0.20 \\
\hline
\end{tabular}

quency of division/differentiation/lignification patterns of the cells by using flow cytometry analysis and laser scanning microscopic imaging. Technical details of bamboo suspension culture model are discussed in this study.

\section{Materials and Methods}

\subsection{Plant Materials}

Plant tissues, i.e. shoots, axillary shoots, leaves, nodes, and culms, were collected from a field-grown and/or a cultivated madake bamboo ( $P$. bambusoides Sieb. et Zucc.), frozen in liquid nitrogen, and stored at $-80^{\circ} \mathrm{C}$. Suspension cultured cells were also prepared at appropriate periods as described below and used as materials.

\subsection{Carbohydrates (CH)-Degrading Activity Assay}

Approximately $10-70 \mathrm{mg}$ of freeze-dried powder of bamboo suspension cells/ tissues were suspended into 1 $\mathrm{ml}$ of $100 \mathrm{mM} \mathrm{CH}$ solutions (cellobiose, maltose, and sucrose) in each well of 12-well micro-plate, and incubated at $25^{\circ} \mathrm{C}$ for 24 hours. The reaction mixtures were centrifuged at $10,000 \times \mathrm{g}$ for $1 \mathrm{~min}$, and the supernatants were filtered through a $0.45 \mu \mathrm{m}$ filter (Amicon UltrafreeMC, Millipore, USA). The filtrates were then analyzed by HPLC as described by Ogita et al. [5] with modifications. Briefly, a Cosmosil Sugar-D column ( $4.5 \mathrm{~mm}$ i.d., $250 \mathrm{~mm}$ in length, Nacalai, Japan) was set at $40^{\circ} \mathrm{C}$ with $75 \%(\mathrm{v} / \mathrm{v})$ acetonitrile at a flow rate of $1 \mathrm{ml} / \mathrm{min}$. Cellobiose, maltose, and sucrose were monitored with a refractive index (RI) detector (RI-101, Shodex, Japan). The $\mathrm{CH}$-degrading activity was calculated based on the remaining amount of cellobiose/maltose/sucrose $(\mu \mathrm{mol})$ in the supernatant of reaction mixture after 24 hour-reaction.

\subsection{Suspension Culture}

Callus and suspension cultures of $P$. bambusoides were generated as described by Ogita [2]. Approximately $1 \mathrm{~g}$ FW of callus tissues was suspended in $100 \mathrm{ml}$ of liquid modified half strength Murashige and Skoog [7] medium (m1/2MS) supplemented with $10 \mu \mathrm{M}$ 2,4-dichlorophenoxyacetic acid (2,4-D) in a $300-\mathrm{ml}$ flask. The flasks were placed on a rotary shaker at $100 \mathrm{rpm}$ in the dark at $25^{\circ} \mathrm{C}$. Suspension cells were generated within 3 weeks after the initial culture. A portion of the liquid suspension cells (ca. 2 - $4 \mathrm{ml}$ ) was transferred to the same medium at 2-week intervals.

\subsection{Growth Regulation of Suspension Cells}

A portion of the liquid suspension cells was suspended in $50 \mathrm{ml}$ of fresh $\mathrm{m} 1 / 2 \mathrm{MS}$ media supplemented with $10 \mu \mathrm{M}$ 2,4-D or $10 \mu \mathrm{M}$ gibberellic acid $\left(\mathrm{GA}_{3}\right)$ in 200 -ml flasks at cell density of $4 \%(\mathrm{v} / \mathrm{v})$ sedimented cell volume (SCV). The flasks were placed on a rotary shaker at $100 \mathrm{rpm}$ in the dark at $25^{\circ} \mathrm{C}$. Changes in the SCV value were monitored during the 14 days of culture period. The SCV was measured by holding a liquid suspension cells for $15 \mathrm{~min}$ in a $50 \mathrm{ml}$ centrifugation tube graduated in milliliters [8].

\subsection{Flow Cytometry (FCM)}

The cultured suspension cells (ca. 1 g FW) were collected from each flasks, treated with $1 \mathrm{ml}$ of a chopping buffer ( $50 \mathrm{mM}$ Tris-HCl, $50 \mathrm{mM} \mathrm{NaHSO}{ }_{3}, 1 \%$ (v/v) TritonX-100, $140 \mathrm{mM}$ 2-mercptoethanol), carefully minced with a blade, and filtered using a tube with cell strainer cap (REF352235, BD Falcon, USA) for extraction of nuclei. The resulted nuclei were stained with $5 \mu \mathrm{M}$ Sytox Green. On average, 10,000 nuclei were counted per sample with a flow cytometer (FACS Calibur HG, BD, USA).

\subsection{Lignification Capacity of Bamboo Suspension Cells}

Lignification capacity of bamboo suspension cells was monitored by phloroglucinol- $\mathrm{HCl}$ reaction [9].

\subsection{Laser Scanning Microscopy (LSM)}

The cultured suspension cells were fixed using $4 \%(\mathrm{v} / \mathrm{v})$ glutaraldehyde solution in sodium phosphate buffer $(0.1$ $\mathrm{M}, \mathrm{pH} 7.2)$, and dehydrated with the ethanol series $(25 \%$, $50 \%, 70 \%, 80 \%, 90 \%$, and $100 \%$ ). They were stained with $0.01 \%$ Safranin and observed using a LSM (LSM510 META, Zeiss, Germany) for characterization of the frequency of division and/or enlargement patterns of the cells.

\section{8. $\beta$-glucosidase (BGL) Activity Assay}

The used media in each culture period were collected 
from the flasks as soluble enzyme fraction 1. Bamboo cultured cells ( 2 g FW) were also collected and grounded in a mortar with liquid nitrogen, extracted with $10 \mathrm{ml}$ of $10 \mathrm{mM}$ potassium phosphate buffer (KPB, $\mathrm{pH} 6.0$ ), and centrifuged $\left(10,000 \times \mathrm{g}, 10 \mathrm{~min}, 4^{\circ} \mathrm{C}\right)$. The supernatants were designated as soluble enzyme fraction 2 . To the resulted precipitates, $10 \mathrm{ml}$ of an extraction buffer (10 $\mathrm{mM}$ KPB containing $2.5 \%(\mathrm{w} / \mathrm{v})$ sodium $N$-lauroylsarcosinate, $100 \mathrm{mM} \mathrm{NaCl}, 1 \mathrm{mM}$ EDTA, pH 6.0) was added and the mixture was homogenized on an ice with a pestle, and gently mixed $\left(3 \mathrm{~h}, 4^{\circ} \mathrm{C}\right)$. After centrifugation $\left(10,000 \times \mathrm{g}, 10 \mathrm{~min}, 4^{\circ} \mathrm{C}\right)$, the supernatants collected were further centrifuged $\left(10,000 \times \mathrm{g}, 10 \mathrm{~min}, 4^{\circ} \mathrm{C}\right)$. They were applied to acetone precipitation for $15 \mathrm{~min}$. at $-35^{\circ} \mathrm{C}$. The precipitates were collected by centrifugation $\left(10,000 \times \mathrm{g}, 10 \mathrm{~min}, 4^{\circ} \mathrm{C}\right)$, and were re-suspended to 10 $\mathrm{mM} \mathrm{KPB} \mathrm{(pH} \mathrm{6.0)} \mathrm{as} \mathrm{membrane-associated} \mathrm{enzyme}$ fraction 1 . The residues were designated as membraneassociated enzyme fraction 2. The protein content of each sample was determined by using a protein assay kit (Bio-Rad, USA) according to the method by Bradford [10].

BGL activity was measured with a synthetic substrate, $p$-nitrophenyl $\beta$-D-glucopyranoside (pNPGlc) [11]. Reaction mixture containing $2 \mu \mathrm{l}$ of DMSO solusion of 500 $\mathrm{mM}$ pNPGlc, $20 \mu \mathrm{l}$ of $1 \mathrm{M} \mathrm{KPB} \mathrm{(pH} \mathrm{6.0)} \mathrm{and} 158 \mu \mathrm{l}$ of distilled water, was pre-incubated at $40^{\circ} \mathrm{C}$ for $5 \mathrm{~min}$. The reaction was initiated by adding each enzyme fraction ( $200 \mu \mathrm{l}$ in total volume), incubated at $40^{\circ} \mathrm{C}$ for $15 \mathrm{~min}$, and then terminated by adding $20 \mu \mathrm{l}$ of $1 \mathrm{M}$ Tris- $\mathrm{HCl}$ buffer ( $\mathrm{pH}$ 8.0). The absorbance at $405 \mathrm{~nm}$ was measured, and the content of $p$-nitrophenol (pNP) in the reaction mixture was calculated using a standard curve prepared under the same conditions. One unit (U) of BGL activity was defined as the amount of enzyme that catalyzing to release $1 \mu \mathrm{mol}$ of pNP per min under the above assay condition.

\section{Results and Discussion}

\subsection{CH-Degrading Activities in Bamboo}

In order to assess $\mathrm{CH}$-degrading activities of Madake bamboo, $100 \mathrm{mM} \mathrm{CH}$ solutions (sucrose, maltose, and cellobiose) were fed to the freeze-dried powder of various tissues and suspension cells, and decrease in the $\mathrm{CH}$ in 24 hours was measured by HPLC analysis. The results were summarized in Table 1. Sucrose, the major transport form of photo-assimilated carbon and a source of energy for plants, was highly degraded by shoots $(9.7$ $11 \mu \mathrm{mol} / \mathrm{h} / \mathrm{mg} \mathrm{DW})$ and suspension cells $(3.4 \mu \mathrm{mol} / \mathrm{h} / \mathrm{mg}$ DW). This feature is similar to the Hachiku bamboo cells [5]. The suspension cells could also degrade maltose, an important intermediate in the digestion of starch, at a late of ca. $2.5 \mu \mathrm{mol} / \mathrm{h} / \mathrm{mg}$ DW. Interestingly, cellobiose, a partial form in the digestion of plant cell wall, was degraded by juvenile tissues like suspension cells (4.1 $\mu \mathrm{mol} / \mathrm{h} / \mathrm{mg} \mathrm{DW})$ and shoots $(1.3-2.0 \mu \mathrm{mol} / \mathrm{h} / \mathrm{mg} \mathrm{DW})$. Other mature tissues such as axillary shoots, leaves, nodes, and culms had weaker $\mathrm{CH}$-degrading activity than suspension cells and shoots. Based on this finding, we speculated that an activity to degrade cellobiose will correlate with an early developmental process of bamboo cells.

\subsection{Growth Patterns of Suspension Cells}

Since 2,4-D/GA 3 have co-stimulative/suppressive effects to cell division and wall development in Coleus blumei [12], they were independently applied to the bamboo suspension cells for regulation of the growth. Changes in SCV and FW during the culture period were monitored as shown in Figures 1(a) and (b). Bamboo suspension cells in 2,4-D-containing medium showed a typical growth

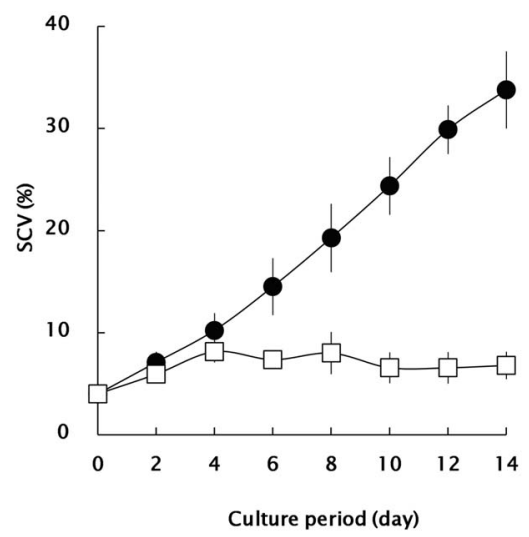

(a)

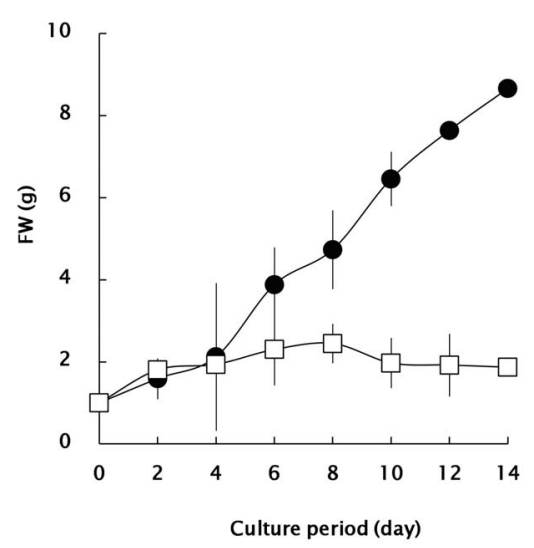

(b)

Figure 1. Growth profiles of Madake bamboo suspension cells in m1/2MS medium, containing $10 \mu \mathrm{M}$ 2,4-D (closed circle) and $10 \mu \mathrm{M} \mathrm{GA}$ (open square). (a): SCV value was calculated as the percentage of sedimented cell volume $(\mathrm{ml})$ per 50-ml medium; (b): Fresh weight (FW) of suspension cells. All data are expressed as mean $\pm \operatorname{SE}(n=3)$. 
pattern as previously documented [8]. There was a lag growth phase for ca. 6 days, after that, the suspension cells showed an active growth during culture period. The SCV and FW reached $34 \%(\mathrm{v} / \mathrm{v})$ and $8.7 \mathrm{~g}$, respectably, in the 2,4-D-containing medium while only $7 \%(\mathrm{v} / \mathrm{v})$ and $1.9 \mathrm{~g}$ in $\mathrm{GA}_{3}$-containing medium in 14 days.

\subsection{Mitotic Activity and Histological Features of Suspension Cells}

Proportion of mitotically active cells ( $S$ to $G_{2} / M$ phases) was summarized in Figure 2. Under the 2,4-D condition mentioned above, mitotically active cells were estimated from $14.9 \%$ (day 0) to $29.5 \%$ (day 8 ). In contrast, only $5.3 \%$ cells (day 8 ) were detectable under the $\mathrm{GA}_{3}$ condition.

In order to investigate the frequency of division/differentiation/lignification patterns of bamboo suspension cells, LSM observation with safranin staining was performed. Tiny cytoplasmic dense cells which have pearl bluish auto-fluorescent signal in the thin primary cell wall and strong orange signal in the nucleus at the log phase (day 8) as shown in Figure 3(a). In contrast, elongation and wall thickening of cultured cells strongly signalized in orange were detectable under the $\mathrm{GA}_{3}$ condition at day 8 (Figure 3(b)). Almost all cells cultured under the $\mathrm{GA}_{3}$ condition elongated/enlarged at the end of the period (day 14). The resulted cells were subjected to phloroglucinol- $\mathrm{HCl}$ reaction to evaluate lignification pattern. As shown in Figure 4, the cells cultured under the $\mathrm{GA}_{3}$ condition were stained with pale pink to red while any positive staining could not be detected in the cells cultured under the 2,4-D condition.

Gibberellin was known as a constituent for increasing fiber cell differentiation and secondary wall deposition in wheat (Triticum aestivum L.) culms [13]. It was also mentioned that the appearance to BGL activity coincided with lignification in T. aestivum suspension cells [14].

As our result indicates that proliferation/lignification were clearly controlled under the $2,4-\mathrm{D} / \mathrm{GA}_{3}$ conditions in bamboo suspension cells, we applied this novel bamboo suspension cell culture model to evaluate the specificity/variability of BGL activity involved in division/ differentiation/lignification.

\subsection{BGL Activity of Suspension Cells}

Total activity of BGL (Figure 5(a)) was expressed as the sum of soluble enzyme fractions 1 and 2 and membraneassociated enzyme fractions 1 and 2 (see Materials and
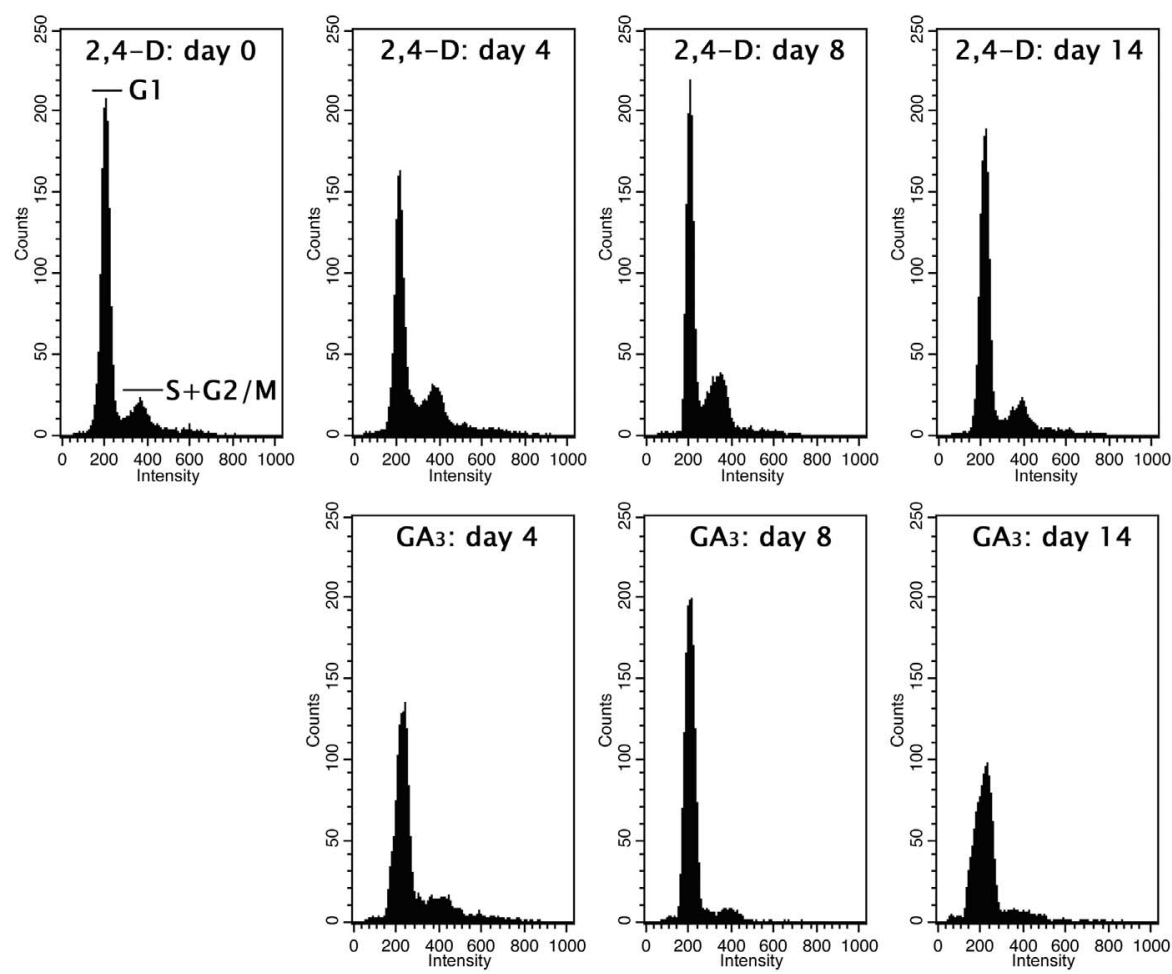

Figure 2. FCM analysis of Madake bamboo suspension cells. The bamboo suspension cells cultured in m1/2MS medium, containing $10 \mu \mathrm{M}$ 2,4-D and $10 \mu \mathrm{M} \mathrm{GA}_{3}$ were collected at day $0,4,8$, and 14, respectively (See Figure 1). The parameters were set as follows. FSC detector (voltage: E00, amplified gain: 1.65, mode: log), SSC detector (voltage: 226, amplified gain: 1.00, mode: log), FL1 detector (voltage: 215, amplified gain: 1.00, mode: linear), FL1-A detector (amplified gain: 1.80, mode: linear), FL1-W detector (amplified gain: 3.00, mode: linear). 

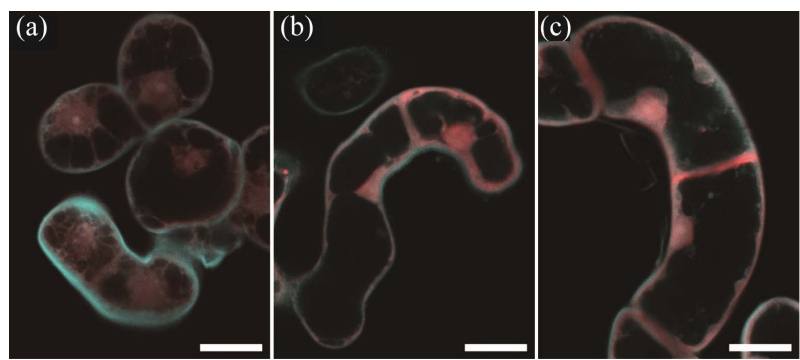

Figure 3. LSM imaging of Madake bamboo suspension cells stained with $0.01 \%$ Safranin. (a): Image of the cells cultured in m1/2MS medium containing $10 \mu \mathrm{M}$ 2,4-D (day 8); (b) and (c): Image of the cells cultured in $\mathrm{m1} / 2 \mathrm{MS}$ medium, containing $10 \mu \mathrm{M} \mathrm{GA}_{3}$ (day 8 and 14), respectively. Images were acquired using plane scan mode. Scale bars $=20 \mu \mathrm{m}$. The objective lens was a C-Apochromat $40 \times / 1.2 \mathrm{~W}$ corr. Channel specification was as follow: Plane scan: Blue diode laser $405 \mathrm{~nm}, 10.0 \%$; Argon laser $488 \mathrm{~nm}, 5.0 \%$; He-Ne laser 543 nm, 40.0\%; Main Beam Splitter: HFT405/488/ 543/633; Beam Splitter 1: NFT 545; Beam Splitter 2: NFT 490; Filter; 550-625, BP 420-480 IR, BP505-530.

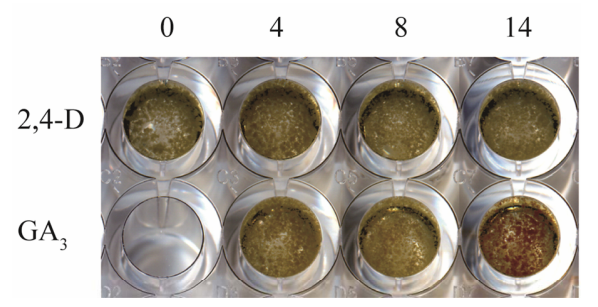

Figure 4. Lignification profiles of Madake bamboo suspendsion cells. The bamboo suspension cells cultured in m1/2MS

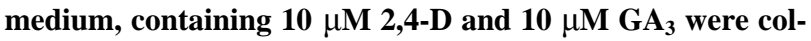
lected at day $0,4,8$, and 14 , respectively (See Figure 2 ).

methods). The total activity of the cells grown under the 2,4-D condition increased from $4.8 \mathrm{U}$ in day 2 to $26.2 \mathrm{U}$ in day 14 (ca. 5.5-fold) while a slight reduction, from 4.4 $\mathrm{U}$ in day 2 to $2.1 \mathrm{U}$ in day 14 (ca. 0.5 -fold), occurred when cell division was suppressed under the $\mathrm{GA}_{3}$ condition. The variation in the total protein which showed similar pattern with the total activity (Figure 5(b)) gave the specific activity of BGL. The activity slightly increased from $0.3 \mathrm{U} / \mathrm{mg}$ protein in day 2 to $0.5 \mathrm{U} / \mathrm{mg}$ protein in day 14 (ca. 1.9-fold) under the 2,4-D condition while a stable value (ca. $0.2 \mathrm{U} / \mathrm{mg}$ protein) was obtained under the $\mathrm{GA}_{3}$ condition (Figure 5(c)).

The ratio of the enzyme activity of each fraction was also calculated as shown in Figures 6(a) and (b). The ratio of the soluble enzyme fractions ( 1 and 2$)$ to the membrane-associated enzyme fractions ( 1 and 2$)$ under the 2,4-D condition was 2 to 8 during the culture period. The major activity was detected as the membrane-associated enzyme fraction 1 (ca. $70 \%$ of the total activity). On the other hand, activity of the soluble enzyme fractions ( 1 and 2), interestingly, increased up to ca. $65 \%$ in

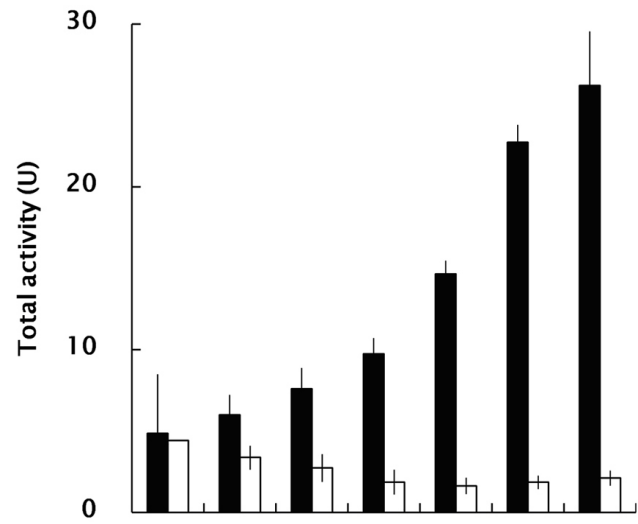

(a)

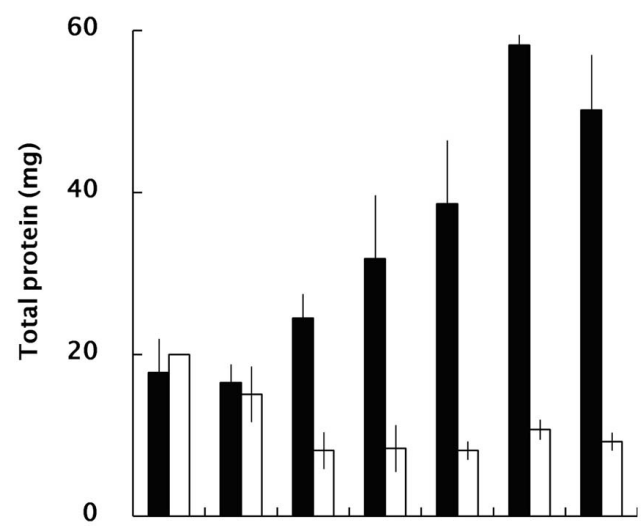

(b)

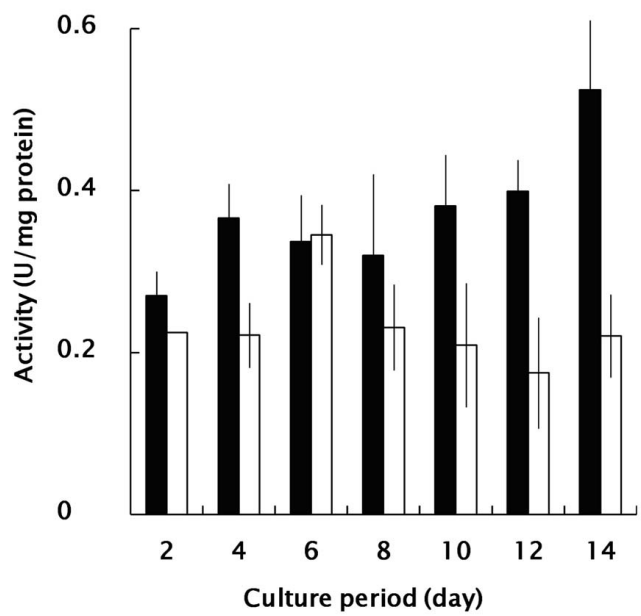

(c)

Figure 5. Effect of 2,4-D and $\mathrm{GA}_{3}$ on $\beta$-glucosidase activity of Madake bamboo suspension cells cultured in m1/2MS medium containing $10 \mu \mathrm{M}$ 2,4-D (closed bars) and m1/2MS medium containing $10 \mu \mathrm{M} \mathbf{G A}_{3}$ (open bars). The samples were collected at day $2,4,6,8,10,12$ and 14 , respectively (See Figure 1). All data are expressed as mean $\pm \mathrm{SE}(n=3)$. (a) and (b): Total activity of $\beta$-glucosidase, and total protein were expressed as the sum of soluble enzyme fractions 1 and 2 and membrane-associated enzyme fractions 1 and 2 (see Materials and methods); (c): Specific activity calculated from the data in (a) and (b). 


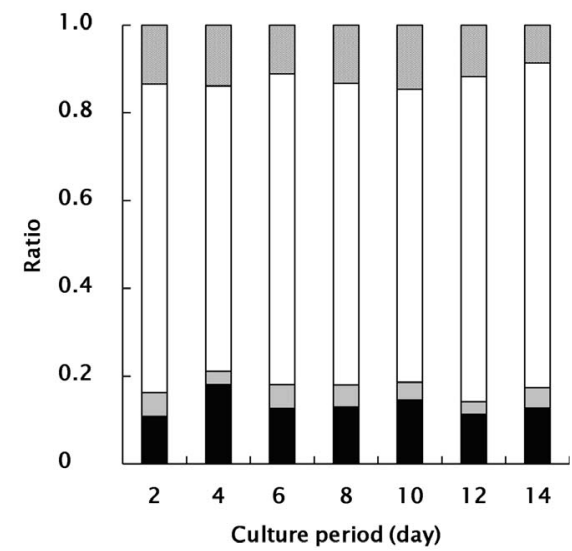

(a)

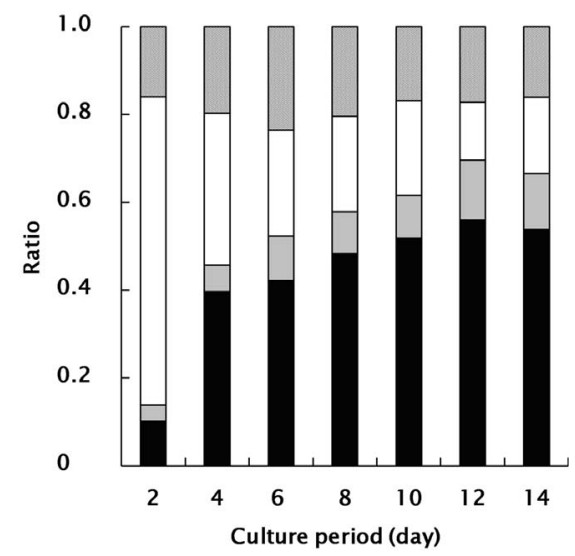

(b)

Figure 6. The ratio of $\beta$-glucosidase activity of Madake bamboo suspension cells cultured in $\mathrm{m} 1 / 2 \mathrm{MS}$ medium containing $10 \mu \mathrm{M}$ 2,4-D (a) and m1/2MS medium containing 10 $\mu \mathrm{M} \mathrm{GA} 3$ (b). The samples were collected at day $2,4,6,8,10$, 12 and 14, respectively (See Figure 1). Soluble enzyme fractions 1 (closed bars) and 2 (gray bars), and membraneassociated enzyme fractions 1 (open bars) and 2 (wavy gridded bars) (see Materials and methods).

total under the $\mathrm{GA}_{3}$ condition in inverse proportion to the membrane-associated enzyme fractions (1 and 2) during the culture period. The major activity was detected as the soluble enzyme fraction 1 in the medium.

As supported by SCV, FW, FCM and LSM analysis (Figures 1-4), cell division was actively enhanced under $10 \mu \mathrm{M}$ 2,4-D condition and relatively high BGL activity could be seen (5.5-fold) in bamboo suspension cultured cells. The major BGL activity found in membrane associated enzyme fraction 1 (ca. $70 \%$ of the total activity), which could be solubilized in the presence of $2.5 \%(\mathrm{w} / \mathrm{v})$ sodium $\mathrm{N}$-lauroylsarcosinate, $100 \mathrm{mM} \mathrm{NaCl}$, and $1 \mathrm{mM}$ EDTA. In rice (Oriza sativa), for example, activities of cell wall-associated BGL during germination were characterized [15]. This enzyme appeared to be ionically bound to cell walls and was solubilized with $1 \mathrm{M} \mathrm{NaCl}$ and its activity increased over 8-fold during germination. The functions of the enzyme were expected for hydrolysis and modification of oligosaccharides in cell walls of germinating rice seeds. As bamboo suspension cells showed abundant deposition of $\beta$-glucan compounds in cell wall during proliferation condition [2], another possibility was suggested that the presence of a $\beta$-glucanase with $\beta$-glucosidase activity like Hordeum vulgare [16].

Although the total BGL activity slightly reduced under the $\mathrm{GA}_{3}$ condition as shown in Figure 5, distinct increasing in soluble BGL activity was detected (see Figure 6) in bamboo suspension cells. As $10 \mu \mathrm{M} \mathrm{GA}_{3}$ is a promortive phytohormone on lignification in bamboo suspension cells, it is expected that the major activity found in the soluble enzyme fraction 1 will contain a specific BGL for hydrolizing monolignol glycosides. A coniferin BGL was identified from xylem tissue of Pinus contorta [17]. In phylogenetic analysis of Arabidopsis thaliana glycoside hydrolase family 1 was carried out and BGLU45 and BGLU46 which categorized a cluster with Pinus contorta coniferin BGL were characterized [18].

Although we should conduct further investigations for isolation, characterization, and structure elucidation of expected BGL(s) from enzymological and genetic point of view, it is safe to conclude that the presented suspension cell culture model can be used as a tool for characterization of physiological and molecular biological events on cell division/differentiation/lignification of Madake bamboo with an efficient transformation protocol [19]. And such investigations are now in progress.

\section{Acknowledgements}

This research was supported in part by a Grant-in-Aid for scientific research, C (22580387) from the Japan Society for the Promotion of Science.

\section{REFERENCES}

[1] N. Bystriakova, V. Kapos and I. Lysenko, "Bamboo Biodiversity," UNEP-WCMC/INBAR, Cambridge, 2004. http://www.inbar.int/publication/PDF/INBAR_BR_8.pdf

[2] S. Ogita, "Callus and Cell Suspension Culture of Bamboo Plant, Phyllostachys nigra," Plant Biotechnology, Vol. 22, No. 2, 2005, pp. 119-125. doi:10.5511/plantbiotechnology.22.119

[3] A. Baba, S. Hasezawa and K. Syono, "Cultivation of Rice Protoplasts and Their Transformation Mediated by Agrobacterium Spheroplasts," Plant and Cell Physiology, Vol. 27, No. 3, 1986, pp. 463-471.

[4] T. Nagata and F. Kumagai, "Plant Cell Biology through the Window of the Highly Synchronized Tobacco BY-2 Cell Line," Methods in Cell Science, Vol. 21, No. 2, 1999 , pp. 123-127. doi:10.1023/A:1009832822096 
[5] S. Ogita, S. Ohki and Y. Kato, "Uptake of Carbohydrates by Suspension Cultured Cells of Bamboo Plants," In: J. A. Teixeira da Silva, Ed., Floriculture Ornamental and Plant Biotechnology, Global Science Books, Isleworth, 2008, pp. 240-244.

[6] J. R. K. Cairns and A. Esen, " $\beta$-Glucosidases," Cellular and Molecular Life Sciences, Vol. 67, No. 20, 2010, pp. 3389-3405. doi:10.1007/s00018-010-0399-2

[7] T. Murashige and F. Skoog, "A Revised Medium for Rapid Growth and Bioassays with Tabacco Tissue Cultures," Physiologia Plantarum, Vol. 15, No. 3, 1962, pp. 473-479. doi:10.1111/j.1399-3054.1962.tb08052.x

[8] S. Ogita, N. Kikuchi, T. Nomura and Y. Kato, "A Practical Protocol for Particle Bombardment-Mediated Transformation of Phyllostachys Bamboo Suspension Cells," Plant Biotechnology, Vol. 28, No. 1, 2011, pp. 43-50.

[9] S. M. Siegel, "On the Biosynthesis of Lignins," Physiologia Plantarum, Vol. 6, No. 1, 1953, pp. 134-139. doi:10.1111/j.1399-3054.1953.tb08937.x

[10] M. M. Bradford, "A Rapid and Sensitive Method for the Quantitation of Microgram Quantities of Protein Utilizing the Principle of Protein-Dye Binding," Analytical Biochemistry, Vol. 72, No. 1-2, 1976, pp. 248-254. doi:10.1016/0003-2697(76)90527-3

[11] M. Matsuura, J. Sasaki and S. Murao, "Studies of $\beta$ Glucosidases from Soybeans That Hydrolyze Daidzin and Genistin: Isolation and Characterization of an Isozyme," Bioscience, Biotechnology and Biochemistry, Vol. 59, No. 9, 1995, pp. 1623-1627. doi:10.1271/bbb.59.1623

[12] R. Aloni, "Role of Auxin and Gibberellins in Differentiation of Primary Phloem Fibers," Plant Physiology, Vol. 63, No. 4, 1979, pp. 609-614. doi:10.1104/pp.63.4.609

[13] S. Lev-Yadun, A. Beharav, R. Di-nur and S. Abbo, "Gibberellic Acid (GA) Increases Fiber Cell Differentiation and Secondary Cell-Wall Deposition in Spring
Wheat (Triticum aestivum L.) Culms," Plant Growth Regulation, Vol. 27, No. 3, 1999, pp. 161-165. doi:10.1023/A:1006167531587

[14] W. Hösel, A. Fiedler-Preiss and E. Borgmann, "Relationship of Coniferin $\beta$-Glucosidase to Lignification in Various Plant Cell Suspension Cultures," Plant Cell, Tissue and Organ Culture, Vol. 1, No. 1, 1981, pp. 137148. doi:10.1007/BF02318912

[15] T. Akiyama, H. Kaku and N. Shibuya, "A Cell WallBound $\beta$-Glucosidase from Germinated Rice: Purification and Properties," Photochemistry, Vol. 48, No. 1, 1998, pp. 49-54. doi:10.1016/S0031-9422(97)01099-6

[16] M. Hrmova, A. J. Harvey, J. Wang, N. J. Shirley, G. P. Jones, B. A. Stone, P. B. Høj and G. B. Fincher, "Barley $\beta$-D-Glucan Exohydrolases with $\beta$-D-Glucosidase Activity. Purification, Characterization, and Determination of Primary Structure from a cDNA Clone," Journal of Biological Chemistry, Vol. 271, No. 9, 1996, pp. 5277-5286.

[17] D. P. Dharmawardhana, B. E. Ellis and J. E. Carlson, "A $\beta$-Glucosidase from Lodgepole Pine Xylem Specific for the Lignin Precurcor Coniferin," Plant Physiology, Vol. 107, No. 2, 1995, pp. 331-339. doi:10.1104/pp.107.2.331

[18] L. L. Escamilla-Trevino, W. Chen, M. L. Card, M. C. Shih, C. L. Cheng and J. E. Poulton, "Arabidopsis thaliana $\beta$-Glucosidases BGLU45 and BGLU46 Hydrolyse Monolignol Glucosides," Phytochemistry, Vol. 67, No. 15, 2006, pp. 1651-1660. doi:10.1016/j.phytochem.2006.05.022

[19] S. Ogita, N. Kikuchi, T. Nomura and Y. Kato, "The Mutated Acetolactate Synthase Gene from Rice as a Non-Antibiotic Selection Marker for Transformation of Bamboo Cells," American Journal of Plant Sciences, Vol. 3, No. 3, 2012, pp. 368-372. doi:10.4236/ajps.2012.33044 